\title{
A war in the head. The new model of Russian propaganda as a Hobbesian time of the disposition of war*
}

\author{
Monika MAZUR-BUBAK**
}

\begin{abstract}
A major part of research into cyber-propaganda discusses the following components it uses: disinformation, creating fake news and employing so-called farm trolls. Actions of this kind do not correspond with the classic division of soft and hard power, since neither can their goals nor the means they utilise be unambiguously defined as coercion, payment, or attraction (Nye, 2009; Mazur-Bubak, 2020). In my article, I describe the hidden means of propaganda employed by the Russian Federation that are additionally supported by a process of armament which cannot be classified as an act of disinformation. These actions aim at achieving a specific type of psychological vantage which stems from an atmosphere of fear, lack of trust, and enmity created within European societies as a result of the incoming information about Russia's increasing military potential as well as new, dangerous means and resources that could be utilised in combat. Such an atmosphere is referred to as a "war in the head", and it pertains to the personal belief that a military conflict is imminent, expressed by individual citizens including those in key public offices. This phenomenon, while bringing to mind Hobbes' state of nature which encompasses the distinct readiness to fight, directly afflicts the internal and international security of European states. Such a situation directly afflicts the internal and international security of European states, for the state of fear and distrust leads to the dismantlement of public democratic institutions, and it does not help in the search for effective methods of solving either internal or global problems (Nussbaum, 2018).
\end{abstract}

\section{KEYWORDS}

cyber-propaganda; Russian Federation; hybrid war; Thomas Hobbes

* This article is a part of the project financed by the Ministry of Science and Higher Education within the "Regional Initiative of Excellence" Programme for 2019-2022. Project no.: 021/RID/2018/19. Total financing: 11897 131,40 PLN.

** Ph. D., Department of Public Economy and Administration, Economic University in Cracow, Poland. E-mail: monikadanutamazur@gmail.com. 


\section{CYBER-PROPAGANDA — BETWEEN HARD AND SOFT POWER}

The differentiation between soft and hard power constitutes one of the most influential concepts in the field of international relations. As demonstrated in a number of studies (Mazur-Bubak, 2020; Nye, 2009), this concept takes on a specific shape in countries with low levels of democratisation of political institutions. Since these countries tend to apply the strategy of international domination through evoking fear and inciting antagonisms, it is difficult to pinpoint the boundary between soft and hard power in their case (Mazur-Bubak, 2020). According to the classic concept of Joseph Nye (Nye, 2009), the difference between the two types of power lies in their methods of utilising the available resources: the means of coercion and payment belong to the strategy referred to as hard power; while those that serve as a paradigm, which is then promoted as effective and desirable, belong to soft power. Some means, however, applied to shape the spheres of international influence by e.g., the Russian Federation and the People's Republic of China, elude this classical division (Nye, 2009).

I will focus on what pertains to actions within cyberspace and the creation of what is called a war in the head ${ }^{1}$. In order to examine them, we first need to briefly scan through the methods applied by the Russian Federation to evoke fear among the citizens of European states.

\section{KEY METHODS OF SPREADING PROPAGANDA IN CYBERSPACE}

Already with his article of 2009, Joseph Nye was arguing that hard power had to do with an actual indicator founded on rational premises; while soft power reflected positive emotions towards a nation or a state. Currently, on the contrary, we observe soft power intertwining with hard power; and somewhere between the two there is the plane where cyber-offensive and cyber-defensive actions take place. Some researchers who examine Russian actions within cyberspace apply the following terms: propaganda (Wilson, 2015), hybrid influence (Pynnöniemi \& Saari, 2017), hybrid war (Hoffman, 2007; Thornton, 2015; Fridman Kabernik, \& Pearce, 2019), cybernetic war (Jamieson, 2018), information war (Fridman, Kabernik, \& Pearce, 2019), or cyber-terrorism. On the other hand, Mark Galeotti argues that Russian policies of exercising influence over the institutions of Western states extend beyond the paradigm of a "hybrid war" and constitute what is closer to a "political war" (Galeotti, 2019);

\footnotetext{
${ }^{1}$ The term "war in the head" was created by the author to symbolical named the process of emergence and maintenance by citizens and political leaders the conviction about the inevitability of an armed conflict, along with all the consequences of feeding that conviction Monika Mazur-Bubak. Term also used in Owen Fitzpatrick speech in contests of research on personal psychology (Fitzpatrick, 2016).
} 
in another paper, he refers to it as a "non-kinetic political war" (Galeotti, 2017). Cybernetic attacks have entered the regular repertoire of offensive actions in states like Iran, Russia, or South Korea (Hoffman \& Levite, 2017).

The most notable propaganda actions include the activities by so-called farm trolls and hacker groups. The farm trolls focus on promoting narrations that aim to destabilise the political scenes of European states by exacerbating social conflicts and radicalising sentiments. Concerning hacking activity, there are numerous examples of hacker groups that remain vaguely connected to political powers. According to data gathered by the Department of Homeland Security (DHS) and the Federal Bureau of Investigation (FBI), two groups of this kind, APT29 and APT28, perform cyclical attacks on the structures of NATO. Principally, they steal classified information and sensitive data about the organisation itself and governments around the world. Most sources identify the connection between the two groups and the Russian government. Moreover, in 2018, the UK National Cyber Security Centre (Reckless campaign, 2018) directly accused Russian Intelligence of conducting attacks via these groups, and referred to them as dangerously and recklessly interfering with citizens' online activities. The attacks targeted both the critical infrastructure as well as the private resources and email accounts of citizens.

At the same time, we need to differentiate between cyber-offensive and cyber-defence; for instance, there are no plans to create a cyber-offensive team within NATO structures (NATO, 2019), even though much effort is spent to prevent attacks within cyberspace, and specialised groups are established to this end. There are many diverse methods of conducting an offensive that utilise cyberspace in varied degrees:

The methods applied included the use of military and non-military tools in an integrated campaign designed to achieve surprise, seize the initiative and gain psychological as well as physical advantages utilizing diplomatic means; sophisticated and rapid information, electronic and cyber operations; covert and occasionally overt military and intelligence action; and economic pressure. Although this problem is not new, some of the means used by Russia, and potentially others, to support proxies and subvert governments are innovative (Military balance, 2015).

Direct attacks observed in Polish cyberspace do not seem much different to those documented in Finland or Sweden. In 2018, a selection of 23 Polish profiles on Facebook was investigated from that angle. Even though there were only 23 of them, their number of visits approximated 53.6 million. Anna Mierzyńska, who authored the investigation, found out that the predominant category of content published on pro-Russian websites and portals was concerned with anti-migrational, anti-Muslim and anti-Ukrainian topics. It also included topics that are not directly linked to the policies of the Russian 
Federation, but nonetheless deepen social conflicts, such as the controversies surrounding vaccinations (Mierzyńska, 2018).

Looking at the activities of Russian propaganda within Poland, we observe Russia interfering on a daily basis with topics that evoke particularly strong emotions. Oftentimes, they are not concerned with politics as such; but instead they touch upon issues that are vital for private citizens, and it is through them that the propagandists deepen the social divisions and incite chaos [...]. It is in its interest to weaken the existent political order, create fear, and increase the feeling of terror. [...] It also results in selective presentation of all negative news on the situation within the institutions and states of the EU and NATO (Mierzyńska, 2018).

At the same time, research into the Russian cyber-propaganda conducted in Sweden has demonstrated that alongside the topics directly concerned with promoting a positive image of the Russian Federation, there is an increase in fake news and controversial content which is designed to incite and aggravate social antagonisms surrounding the crisis in the West, GMO, migration or NATO (Kragh \& Åsberg, 2017). Moreover, studies of social media and information portals conducted in Finland confirm this general mechanism and methodology applied to influence public opinion (Pynnöniemi \& Saari, 2017). Their main goal is to deepen the existing social conflicts and provoke new ones not only via an influx of polarising disinformation and propaganda, but also through the activities of intelligence (Mazur-Bubak, 2020). This aspect of Russian propaganda is sometimes referred to as the fight for the narration. As pointed out by Olga Tokarczuk, ${ }^{2}$ a takeover of the narration constitutes one of the key ways to seize the power:

When this story changes, so does the world. In this sense, the world is made of words. How we think about the world and - perhaps even more importantly — how we narrate it has a massive significance, therefore. A thing that happens and is not told ceases to exist and perishes. This is a fact well known to not only historians, but also (and perhaps above all) to every stripe of politician and tyrant. He who has and weaves the story is in charge (Tokarczuk, 2019).

\section{HOW INFORMATION ABOUT RUSSIA'S MILITARY POTENTIAL INFLUENCES THE INTERNAL POLICIES OF EUROPEAN STATES}

Among the above-mentioned propaganda material there is also a specific type of information that differs in its character from what is referred to as disinformation. It serves a specific purpose: its job is to influence the general living

\footnotetext{
${ }^{2}$ Nobel Prize winner in Literature. Her works is often commented as a creator opposing contemporary populisms and a promoter of human rights and humanism.
} 
standard in European states by instigating an atmosphere of fear and readiness to employ non-democratic means to resolve issues that are considered socially and politically vital. As noted in the previous research: "the main source of information about the acceleration of armament and new technological acquisitions is transmitted via the pro-Russian portal Sputnik.com. Simultaneously, the same portal reports the massive amounts Poland and Czech Republic allocate to the military (sputnik.com)" (Mazur-Bubak, 2020). The process of armament in Russia goes hand in hand with a wide-ranging action of spreading information about the increase in Russia's military potential. This action is undertaken by pro-Russian internet portals and TV channels (Mazur-Bubak, 2020). Such activities are no surprise to those who study international political relations, for they belong to a well-documented mechanism (exemplified, for instance, by the period of the Cold War) designed to establish a psychological vantage. This narration was confirmed in 2012 by the Russian president, who directly referenced the Cold War competition while discussing the politics of the Russian Federation (Putin, 2012).

As it resurfaces on internet portals and media, the information about military training programmes, military potential and innovative combat methods utilising new technologies (Mazur-Bubak, 2020) directly affects the perceptible living standard of European societies. Such an effect is achieved mainly by inciting an atmosphere of terror, helplessness, and the fear of vague, concealed means of combat (hybrid war). Among these, we can particularly observe the fear of military aggression, disorganisation of the political sphere, ineffectiveness of the critical infrastructure or the insufficient potential of national defence systems (when compared to the Russian Federation). The increase of negative emotions, such as fear, terror or frustration, in society leads to a number of consequences. Frustration on its own directly impacts the level of aggression, as was noted by John Dollard and his team, who argue that any occurrence of an aggressive behaviour implicates frustration and, conversely, the occurrence of frustration implicates one or another form of aggression (Dollard et al., 1939: 1).

Martha Nussbaum has noted a similar tendency when it comes to fear, which affects not only social but also political structures (Nussbaum, 2018). She argues that fear in a society is a state of a particular difficulty, and it is often reduced by seeking substitute causes that are easier to find than the genuine roots of the problem. The citizens' radically negative emotions (expressed in the public sphere) can lead to a decrease in the efficiency of modern democratic structures and institutions commanding an adequate standard of public debate and, consequently, undermine social trust. Nussbaum observes the following about the issue of anti-migrational campaigns in Switzerland:

Real issues are being swept under the rug, and symbolic issues that have no demonstrable connection to the real issues are taking their place. Instead of engaging in 
a difficult but ultimately constructive debate about how to promote social cohesion and continuity in a time of immigration, and about how to move toward greater empowerment for women, people are encouraged to feel that they are making progress by engaging in a purely notional campaign against a threat that does not exist (Nussbaum, 2012: 47).

Unfortunately, once the fight for symbols has commenced it cannot be dismissed as a marginal issue, for the appropriation of symbols and placing them in a specific context constitutes a momentous act of taking over both the historical narrative and the narrative concerned with the ongoing events.

We can take it one step further and argue that any action by an authority directed at naming a scapegoat not only prevents any chance to solve the actual problem, but in fact compromises the democratic structures founded on justice, as it promotes the politics of exclusion through the heuristics of seeking the enemy in diversity (i.e., among ethnic, national, religious minorities). Nussbaum claims that emotions such as fear, anger, disgust, or terror directly influence the dismantlement of modern democratic institutions. She focuses on the dysfunctional nature of anger, which can be easily evoked among citizens and, then, redirected towards symbolical enemies who are usually members of national, ethnic, religious, or sexual minorities (Nussbaum, 2018). This phenomenon is well known in social psychology and often referred to as aggression displacement (Cowen, Landes, \& Schaet, 1958). As was noted by Leonard Berkowitz in the 1960s, we can observe certain regularities when it comes to selecting a scapegoat either from among groups that were associated with conflict before, or from those that have already been looked at with aversion (Berkowitz, 1962).

The success of the Russian propaganda that results in the disorganisation of the democratic structures inside European states has been discussed in a variety of official sources: “There is strong evidence pointing to Russia as the primary source of disinformation in Europe', said Andrus Ansip, vice-president of the European commission" (EU raises funds, 2018).

The process of antagonisation is deepened when internal tensions are incited and intensified as well as stemming from the actual anxieties and problems of the community. In the discussed case, it is achieved by releasing controversial fake news concerned with vaccinations or genetically modified food. Often, such content has an apparent scientific outline, hence, the average reader perceives it as verified. Moreover, the reader does not usually deem himself sufficiently competent to conduct a lengthy verification of the presented data. Failure to assist the citizens in the process of verifying fake news and identifying the propaganda material, paired with the intensified use of ineffective, scapegoating-oriented methods when handling the authentic social issues, can lead to an escalation of the social conflict - "A growing 
conflict between two opposing political camps has also the capacity to influence people who were initially neutral to become increasingly involved in it." (Reykowski, 2002: 219-202).

What is even worse, the gears of a growing internal conflict tend to polarise the political scene in terms of defining the key issues and threats as well as their suggested solutions. Hence, the political reality becomes split into two incongruent narratives describing disparate images of the world. This state is partly the result of (and also deepened by) the disruption and the eventual rupture of group communication, which is then reduced to seeking and promoting controversial information (either confirmed or false) aimed at discrediting the opposing faction (Reykowski, 2002: 222).

As was rightly noted by Adam Lelonek: "evoking internal tensions and conflicts leading to the polarisation of society and the degradation of the value system that kept it together results in a crisis of public institutions. The state becomes weak, vulnerable to external influences, helpless in the face of political, economical, and military aggression" (Lelonek, 2019: 14).

\section{HIDDEN GOALS OF THE WIDE-RANGING INFORMATIONAL ACTION ABOUT ARMAMENT CONDUCTED BY THE RUSSIAN FEDERATION}

Thus, we can note that the propaganda spread among European states by the Russian Federation involves a complex mechanism aimed at inciting a reaction of fear and terror and, consequently, installing chaos and panic into the internal politics of these states. Information of this sort is consciously utilised to evoke fear, and added to this is the fact that it is not plausible to dismiss such a reaction as irrational. The combination of partially true information and slogans belonging to the propaganda, while mentioning "armed humanoid bots marching at a military parade" (Ackerman, 2019) or military equipment designed to cause blindness and loss of consciousness (Sendek, 2019), can be compared to a bombardment with fear and terror.

One could ask the question: what is the purpose of the Russian Federation informing the European public opinion of their armament successes and increasing military potential? It cannot be merely about "flexing their muscles", which is sometimes understood as presenting oneself as the stronger opponent who should not be provoked, i.e., the Athenian strategy known from the Melian Dialogue (Tukidydes, 1989: 84-116). On the contrary, these actions appear to serve a certain camouflaged, yet precise goal, which is to cause panic and chaos among the citizens of democratic states. The fact that information about the increase in resources spent on armaments and the intensified military trainings is published and propagated on internet portals controlled by the 
Kremlin (e.g., the above-mentioned Sputnik.com) reaffirms that the efforts to intimidate international opinion are conscious and planned.

The destructive influence that a sole possibility of combat inflicts on a person's life was described by Thomas Hobbes. He concluded that the state of nature is largely dysfunctional when it comes to the individual and collective development, for people who expect an attack find themselves under a continuous pressure which prevents them from being involved in any other activity.

Whatsoever therefore is consequent to a time of Warre, where every man is Enemy to every man; the same is consequent to the time, wherein men live without other security, than what their own strength, and their own invention shall furnish them withal. In such condition, there is no place for Industry; because the fruit thereof is uncertain; and consequently no Culture of the Earth; no Navigation, nor use of the commodities that may be imported by Sea; no commodious Building; no Instruments of moving, and removing such things as require much force; no Knowledge of the face of the Earth; no account of Time; no Arts; no Letters; no Society; and which is worst of all, continual fear, and danger of violent death; And the life of man, solitary, poor, nasty, brutish, and short (Hobbes, 1881: 93-94).

Hobbes described war not only as the state of direct combat, but also a mental construct founded on the belief that an attack is imminent: "So the nature of War, consistent not in actual fighting; but in the known disposition thereto, during all the time there is no assurance to the contrary" (Hobbes, 1881: 93) What is this disposition, then, that renders human life as poor, lonesome, sunless, and short, as Hobbes puts it? It is not solely the number of attacks on a person's life or property - but also the paralysing fear that keeps people from cooperating and developing mutual trust. According to Hobbes, these two aspects of human existence served as the foundation to establishing statehood. We can argue, however, that in the light of modern terminology, Hobbes referred to anxiety rather than to fear; for in the state of nature a person is surrounded by danger, hence the looming, imprecise feeling of anxiety. Fear is also present within the state of nature; however, it is contained within specific frames due to which a person can expect negative consequences as the result of breaching the law. The difference between the two, Hobbes argues, is that while anxiety paralyses us and impedes our development, fear is more civilized, as it has a specific cause and a specific purpose.

Hobbes also observed that people subjected to continued anxiety and pressure behave in a distinctly altered manner. Michael Foucault shared this observation in his discussion of panopticism, i.e., surveillance through the constant pressure inflicted by being monitored. Interestingly, in the context of information overload, this relation is reversed: the fact that individual citizens are actively and constantly monitoring the threat brings about a tangible change to their behaviour. The individuals become "the inmates should be caught 
up in a power situation of which they are themselves the bearer" (Foucault, 1995: 201) for the purpose of panopticon surveillance is not to factually monitor each prisoner, but to maintain an unverifiable power - the prisoners are not supposed to know if they are being monitored at a given moment, but they ought to be convinced they might always be.

The "war in the head" is founded on a similar approach: the information circulated does not need to be true, but it ought to be unverifiable, so as to evoke a more intense anxiety. A citizen under such propaganda can be understood - as Foucault described - as "the object of information, never a subject in communication" (Foucault, 1995: 200). Fake news performs a similar function to that of the screen separating the prisoners from the inspectors: the awareness of their existence makes it unattainable to decisively verify the incoming information on armaments and related policies. In the same manner as the panopticon confuses those prisoners who cannot tell if the inspector is currently monitoring them or not, the information on armaments and planned attacks confuses its audience. Thus, a machinery of dissymetrization is established. The technique of inducing an anxiety resulting from an alleged war among European citizens constitutes a paradigm that bears numerous similarities to the panopticon as the "laboratory of power" and likewise controls social attitudes and ways of behaviour.

The Russian propaganda disseminated throughout cyberspace has both conspicuous and obscure goals. Those more conspicuous and already discussed by researchers and observers include, among others: formulating controversial and often outrageous content leading to a decrease in the standard of public debate. In order to inhibit this process - just as in order to inhibit anger - high skills are required, cooperation between various groups is necessary; however, this is a rarity in a conflicted political space. The fight for "the minds and the hearts" plays itself out on different layers, the first of which is to present the situation as drastically dangerous, embed an atmosphere for the gradual acceptance of the upcoming conflict, and, consequently, to establish new rules of social functioning based on militarism. This militarism, resulting from fear for the future and fuelled by the conviction that armaments are necessary, leads to departure from democratic structures; it also causes citizens to drift apart from one another and to turn to egoisms. Additionally, a number of citizens seek to reduce the tension arising from fear and frustration through the means of discrimination as a tool of self-regulation (Kossowska et al., 2017).

The second layer involves the acceptance of desolation and the rejection of community resulting from fear (i.e., turning away from the atmosphere of mutual help), which prompts the increased support for parties proclaiming the politics of seclusion. Such politics resemble the monarchic form of government that concurs with the aged conviction that in dire times there is no use for the rule of the people or republican rule, but instead there is a need 
for a powerful, centralised authority — as presented by Niccolò Machiavelli (Machiavelli, 2009). ${ }^{3}$

A similar seclusion and desolation are features of the panopticon, which is designed to isolate each individual. In spite of the absence of actual, physical shackles, each person is left alone with their anxieties and fears.

As demonstrated by the example of the Polish political scene, perceiving a military conflict (or a hybrid attack) as a realistic scenario is directly reflected in election results. The IPSOS study conducted in August 2019 on a group of 1006 people points to a definite discord between the voters of the leading parties when it comes to identifying the most imminent dangers threatening Poland. The study illustrates the division of society into two opposing visions of reality, where one of the sides directly follows the hints indicating the feasibility of a military conflict with the Russian Federation (26\% of voters for the ruling party; for comparison, $6-7 \%$ voters of the two main opposition parties share this view). The threat of such a conflict is rated second to the threat imposed by "Gender ideology" and the LGBT movement (54\%). On the contrary, the voters of the two strongest opposition parties identified the following threats: "the climate crisis, water deficit and increasing temperature" (41\% and $52 \%)$, "Poland leaving the EU" (34\% and 35\%), and "the nationalistic movements growing in power" (32\% and 39\%) (Pacewicz, 2019).

The belief in an upcoming Russian attack strengthens the support for the process of dismantling the structures of civil society and democratic institutions. A society convinced of its critical position begins to "eat its own tail" and frantically seeks a "saviour" who would assume responsibility for the situation and protect the citizens. Thus, the cycle of inciting fear is completed, for the society starts to fall into the trap of a self-fulfilling prophecy: the fear is transformed into expectation and finally into anticipation. One person's conviction about an imminent conflict swiftly infects other people and soon spreads across the entire political community, lowering citizens' living standards. Moreover, it renders society more vulnerable in the face of an actual conflict, as it suspends the bonds integrating European states and intrastate communities.

Simultaneously, the fear of military aggression and other threats offers an opportunity for populist parties, because "security is also a matter of perception" - as noted by Jan Zielonka (Zielonka, 2018:2,159). At the same time, the populist manner of conducting internal politics inhibits any solid debate over relevant issues and actual problems, thus, intensifying the chaos. Such a situation, either on the political scene or in social relations, causes far-reaching damage and significantly undermines the effectiveness of liberal-democratic

${ }^{3} \mathrm{He}$ also warned that once transferred under authoritarian rule, power is rarely given back to the people. Hence, republics are more often transforming into principalities than the reverse (Machiavelli, 2009). 
institutions (Zielonka, 2018). Another alarming tendency for the political elite to react inappropriately to intense negative emotions in the community (such as the fear of an attack) has been researched by Emma Hutchison and Roland Bleiker:

Emotions can in this way be directed by elites who are concerned with reinstating political stability and social control. Healing often becomes more about retribution and revenge, rather than a long-term project begetting peace, collaboration and emotional catharsis. The emotions triggered by trauma thus tend to perpetuate existing antagonisms, further entrenching the disingenuous perceptions of identity that may have created violence in the first place (Hutchison \& Bleiker, 2008: 385-404).

Politicians, instead of aiding society to cope with difficult emotions, often stir them up, desiring to use them to establish their own strong position. Given the modern context, we can argue that the relation of power and vantage in a country corresponds with the emotional state of its nation or political community. On the same note, the direction in which the authorities take the narration about the internal and international issues can either lead to a successful dissolution of antisocial emotions (Nussbaum, 2018) or exacerbate the crisis and deepen the dismantlement of civil society by blocking the process of deliberation. The political history of the Polish People's Republic is an accurate example of a dysfunctional narration: in the period of real socialism, the official narratives were nearly entirely fabricated, which resulted in the creation of a phantom sphere of surrogate communication. At the same time, the paradox of a liar was at work: even the information based on facts was treated as a part of this phantom communication. In the modern age, however, the liberation from dysfunctional narratives constitutes an even greater challenge, as it pertains to the specifics of how the cyberspace intertwines with the space of real socio-political relations. Therefore, in order for a narration to become an authentic shield against destructive and asocial political emotions, it needs to be founded on reliable sources. As noted by Corneliu Bjola, such narrations ought to feature at least six normative attributes, among which are:

truthfulness and prudence for demonstrating the nature of the harmful effects of disinformation; accountability, integrity, and effectiveness for establishing the normative standing of the actor to engage in counter-intervention; and responsibility for confirming the proportionality of the response (Bjola, 2018: 305-315).

A reasonable narration on existent threats in a state can be compared to a situation on an airplane: in order to avoid dangers that could result from panic, the passengers are informed about the potential risks in a reserved manner. Similarly, an imbalanced and short-sighted manner of formulating a political narration that entails the incitement of negative emotions can generate 
a self-fulfilling prophecy in which European states, afraid of conflict and already in the process of creating an atmosphere of rivalry and egoism in their internal and international relations, will begin to anticipate the conflict themselves.

\section{A WAR IN THE HEAD AS A SELF-FULFILLING POLITICAL PROPHECY}

The internal situation in a country remaining under the influence of this type of propaganda, countered neither institutionally nor narratively, can be called "a war in the head". This term illustrates the strong conviction of being in a "besieged stronghold". It is a situation when an increasing number of citizens and - what is even more alarming - persons in public office are convinced of an imminent attack on culture and national values on the part of "LGBT communication and the Gender ideology" or an incoming Russian military campaign, as shown by the IPSOS study (Pacewicz, 2019). This adds up to the conviction that self-defence and isolation from others are required; as noted by Nussbaum, fear builds a wall that separates us from the rest of society and, what is worse, serves as a justification for antisocial actions and the omission of the deliberation process in vital issues (Nussabum, 2018). The "war in the head", which is a conviction that one is already at war or that the war is definitely coming, is dangerous for society even at the individual level; for fear and terror have the tendency to infect others, which is best illustrated by the fact that internet users unconsciously participate in promoting propaganda materials in cyberspace (Wanless \& Berk, 2017). Consequently, the political narration is shaped in a socially dysfunctional manner; it then undermines social trust, while lowering the living standard, causing the radicalisation of political opinions, and fuelling existing antagonisms. Some political elites who share the belief in an upcoming attack begin to act in a manner we can refer to as a self-fulfilling prophecy.

The warfare personality sees himself as being at war, not merely a civil or foreign war, but a war knowing no geographic or temporal boundaries. Seeing the world in this way, the warfare personality's own pathologies are thus politicized - the apotheosis of Lasswell's private affect being projected on a public object and being rationalized in the public interest (Robinson \& Post, 1987: 3).

The "war in the head" characterises paranoid political actors who display: projective thinking, hostility, suspiciousness, centrality, delusions, fear of a loss of autonomy, grandiosity (Swanson et al., 1970). On the individual level, a person in a state of paranoia often begins to anticipate their own fears. A similar phenomenon is observed in the case of paranoid political subjects: 
While the paranoid's notion that others are out to get him is often initially inaccurate, it may come to be true (Lemert, 1967). As the paranoid behaves in such a way as to justify his own worst fears, his accusations become self-fulfilling (Robinson \& Post, 1987: 3).

This process is enforced when the media provide content formulated according to the logic of a state of war - even thought the actual enemy has not launched an attack yet. A growing number of citizens start to sense the threat and become eager to choose radical, non-democratic solutions. The crisis and the internal conflict become deeper due to the thought structures ("a war in the head") of the people in key public offices. This does not stem from a regular populism, but from the politicians' deep conviction about an actual war, in which they all take part, which is affirmed by the structure and form of the statements expressed by key politicians of European states, in particular, by the militarisation of the terminology. The thought structures affecting the way citizens perceive the level of threat are transmitted alongside the specific use of language itself.

Within the political context, waging a war against an opponent serves as an apt justification for the majority of actions that stand against the premises of a state, ones that would be socially unacceptable in different circumstances. In other words, if the politicians who are convinced the state is at war manage to persuade a sufficient number of people, they will bring about a certain form of exacerbated conflict, which can then lead to a lack of diligence in international relations. The convictions held by those in key political office are crucial for internal and international politics, as fear has the tendency to infect others: the "war in one's head" can be easily transmuted into a "war in many heads". From here, it is only a small step for the conflict to become a nearly factual construct - which is best exemplified by the steadily high support for populist parties. A similar mechanism of the increase in fear as the main cause for the ethnic conflicts in the former Yugoslavia was described by David Lake and Donald Rotchild:

As groups begin to fear for their physical safety, a series of dangerous and difficult-to-resolve strategic dilemmas arise that contain within them the potential for tremendous violence. As information failures, problems of credible commitment, and the security dilemma take hold, the state is weakened, groups become fearful, and conflict becomes likely. [...] Together, these between-group and within-group strategic interactions produce a toxic brew of distrust and suspicion (Lake \& Rothchild, 1998: 4).

These observations were confirmed by Janusz Reykowski, who presented the paradigm for the behaviour of conflicted groups in a situation of an exacerbated conflict, in which he includes: the polarisation of political opinions, increased group cohesion, or the activation of initially passive observers 
(Reykowski, 2002: 222). A war of this kind does not have an "exit procedure", i.e., it does not anticipate a peaceful solution - on the contrary, it is designed to be a permanent state. Just as has been expressed by Carl Schmitt: the state of emergency becomes continuous (H. Hofmann, Legitimität Gegen Legalität der Weg der Politischen Philosophie Carl Schmitts, quoted after: Skarzyński, 1992: 97).

It is, therefore, a self-driven mechanism, which prompts a constantly growing part of society to believe in the imminent threat of war. In the case of Poland, this war is to be waged on many frontlines: against the LGBT communities, refugees, compatriots representing opposite world views, judges, socialism and everyone who refuses to function in the state of war. At the same time, by focusing all attention on the overblown internal animosities, one loses the overview of the situation outside of the imaginary reality of fomented conflicts.

\section{CONCLUSION}

The majority of studies into Russian propaganda point to the dangers arising from fake news, hackers' attacks and the activity of so-called farm trolls. Disinformation activities were deemed particularly hazardous also by the European Commission:

Disinformation is understood as verifiably false or misleading information that is created, presented and disseminated for economic gain or to intentionally deceive the public, and may cause public harm. Public harm includes threats to democratic processes as well as to public goods such as Union citizens' health, environment or security (European Commission, 2018).

We cannot ignore the fact that by evoking strong emotions, cyber-propaganda does not simply transform its recipients into passive consumers, but also recruits them as active actors involved in its dissemination (Wanless \& Berk, 2017) in a similar way in which in panotism individuals become both subjects and carriers of imposed power. Hence, we can argue that the management of emotions within political communities directly influences the level of democratisation of national institutions, especially as a result of the use of cyberspace and means of mass communication. The actions of Russian propaganda afflict these institutions by instilling an atmosphere that is hostile to the deliberation processes, decreasing the quality of public debate, and strengthening the electorate of populist parties. This strategy is being consciously utilised by the Russian Federation as one of the most effective strategies to gain influence over the internal politics of European states (Kragh \& Åsberg, 2017; Pynnöniemi \& Saari, 2017; Fridman, Kabernik, \& Pearce, 2019). Most analytical studies do not pay much attention to the mechanisms of the Russian propaganda 
employed to inform about planned and conducted military trainings, advanced equipment and increased armament expenditure which resurfaces on Russia Today and internet portals such as Sputnik.com. Most of this information cannot be verified, therefore, it cannot be considered a disinformation (according to the definition posed by the European Commission from 2019). Its dissemination leads to increased social insecurity and fear of previously unknown forms of hybrid attacks, and as such it appears to be equally intense and effective as other forms of cyber-propaganda. The information about armaments has some foundation in reality, hence, it is more difficult to ignore; and moreover, the reaction it causes cannot be dismissed as irrational. At the same time, the fear and terror that result from the intentionally disseminated information about Russia's military power are being used by the European political elites in a manner that is dysfunctional to democratic structures themselves. Instead of lowering the levels of fear, preventing the cascading of negative emotions through verification of the incoming information, and assuming a correct, socially functional narrative facilitating the process of catharsis, the elites actively add to the incitement of antagonisms (Hutchison \& Bleiker, 2008: 385-404). The growing conviction within European societies about an impending armed conflict (fuelled here by political elites) can be compared to the Hobbesian state of nature, in which, although there are no direct fights, there is a belief that armed conflict is becoming inevitable. This definitely (although it is the result of propaganda itself) encourages both citizens and governments to take action, shaping the political order away from the current norms.

On the one hand, analysis of the international situation and a realistic evaluation of the threat level should be a part of an ordinary and standard procedure; on the other hand, putting excessive emphasis on the threat can result in an increase in extremist attitudes and the approval for radical actions which fuel ethnic and international conflicts (Lake \& Rothchild, 1998). Thus, the "war in the head" is a dangerous state not only because of the growing intensity of internal conflicts, but also because it makes a society vulnerable to outside manipulations. Additionally, the "management of anger" that involves its incitement and redirecting can at a certain point spiral out of control and lead to attacks within the community itself.

\section{BIBLIOGRAPHY}

Ackerman, E. (2019). Russian Humanoid Robot to Pilot Soyuz Capsule to ISS This Week Skybot F-850 will spend a week on the ISS charming astronauts with its sense of bumour, IEEE Spectrum, 19 Aug 2019. Retrieved from: https://spectrum.ieee.org/automaton/robotics/space-robots/russian-humanoid-robot-to-pilot-soyuz-capsule-to-iss-this-week (30.01.2020).

Ball, M. \& Killough, H. (1956). International relations. London: Ronald Press Company. Berkowitz, L. (1962). Aggression: A social psychology analysis. New York: McGraw-Hill. 
Bjola, C. (2018). The ethics of countering digital propaganda. Ethics \& International Affairs, 32(3), 305-315. Doi: 10.1017/S0892679418000436.

Budzisz, M. (2019). Chcesz pokoju — szykuj się do wojny. Retrieved from: https://tysol.pl/ a37900--Tylko-u-nas-Marek-Budzisz-Chcesz-pokoju-Szykuj-sie-do-wojny-W-Kijowie-mysla-inaczej (28.11.2019).

Cowen, E.L., Landes, J., \& Schaet, D.E. (1958). The effects of mind frustration on the expression of prejudiced attitudes. Journal of Abnormal and Social Psychology, 58, 33-38.

Dollard, J., Miller, N.E., Doob, L.W., Mowrer, O.H., \& Sears, R.R. (1939). Frustration and aggression. London: Yale University Press. Doi: 10.1037/10022-000.

EU raises funds. (2018). EU raises funds to fight 'disinformation war' with Russia. The Guardian, 5.12. Retrieved from: https://www.theguardian.com/world/2018/dec/05/eu-disinformation-war-russia-fake-news (25.11.2019).

European Commission. (2018). Joint Communication To The European Parliament, The European Council, The Council, The European Economic And Social Committee And The Committee Of The Regions. Action Plan against Disinformation, Brussels.

Fitzpatrick, O. (2016). Mind control: How to win the war in your head. TEDxTallaght. Retrieved from: https://www.youtube.com/watch?v=rBwQZv3_OXE (17.12.2019).

Foa, R., Mounk S., \& Mounk Y. (2017). The signs of deconsolidation. Journal of Democracy, 28(1), 5-16.

Foucault, M. (1995). Discipline and punish: The birth of the prison. New York: A Division of Random House. Retrieved from: https://monoskop.org/images/4/43/Foucault_Michel_ Discipline_and_Punish_The_Birth_of_the_Prison_1977_1995.pdf (17.12.2019).

Fridman, O., Kabernik, V., \& Pearce, J.C. (2019). Hybrid conflicts and information warfare: New labels, old politics. London: Rienner Publishers.

Galeotti, M. (2017). Russian intelligence is at (political) war. NATO Review, 12.05. Retrieved from: https://www.nato.int/docu/review/articles/2017/05/2/russian-intelligence-is-at-political-war/index.html (03.11.2019).

Galeotti, M. (2019). Rosyjskie operacje wywiadowcze - nowe taktyki, ale nie cele. NATO Review, 24.04. Retrieved from: https://www.nato.int/docu/review/pl/articles/2019/04/26/ rosyjskie-operacje-wywiadowcze-nowe-taktyki-ale-nie-cele/index.html (29.11.2019).

Głowiński, M. (2016). Zła mowa. Jak nie dać się propagandzie. Warszawa: Wydawnictwo Wielka Litera.

Hobbes, Th. (1881). Leviathan; or, The matter, forme, and power of a Common-wealth Ecclesiasticall and Civill. Oxford: J. Thornton. Retrieved from: http://archive.org/details/ b24880383 (30.01.2020).

Hoffman, F.G. (2007). Conflict in the 21st century: The rise of bybrid wars. Arlington: Potomac Institute for Policy Studies.

Hoffman, W. \& Levite, A. (2017). Can active measures belp stabilize cyberspace?. Carnegie Endowment for International Peace. Retrieved from: https://carnegieendowment.org/files/ Cyber_Defense_INT_final_full.pdf (28.11.2019).

Hutchison, E. \& Bleiker, R. (2008). Emotional reconciliation reconstituting identity and community after trauma. European Journal of Social Theory, 11(3), 385-403.

Jamieson, K.H. (2018). Cyberwar. How Russian hackers and trolls belped elect a president: what we don't, can't, and do know. Oxford: Oxford University Press.

Kossowska, M., Szwed, P., Czernatowicz-Kukuczka, A., Sekerdej, M., \& Wyczesany, M. (2017). From threat to relief: expressing prejudice toward atheists as a self-regulatory strategy protecting the religious orthodox from threat. Frontiers in Psychology, 29, 873. Retrieved from: https://doi.org/10.3389/fpsyg.2017.00873 (10.03.2020). 
Kragh, M. \& Åsberg, S. (2017). Russia's strategy for influence through public diplomacy and active measures: the Swedish case. Journal of Strategic Studies, 40(6), 773-816. Doi: 10.1080/01402390.2016.1273830.

Lake, D. \& Rothchild, D. (1998). The international spread of ethnic conflict: Fear, diffusion, and escalation. Princeton: Princeton University Press.

Lelonek, A. (2019). Walka o narrację. Polska Zbrojna, 2, 14-16.

Lemert, E. (1967). Paranoia and the dynamics of exclusion. Human deviance, social problems and social control. Englewood Cliffs: Prentice-Hall.

Locke, J. (1992). Dwa traktaty o rzadzie. Warszawa: Państwowe Wydawnictwo Naukowe.

Machiavelli, N. (2009). Ksiaże. (Cz. Nanke, Trans.). Warszawa: Wydawnictwo Naukowe PWN.

Marcus, G.E. (2008). Psychologia emocji i polityki, psychologia polityczna. 163-189. In: D.O. Sears, L. Huddy, \& R. Jervis (Eds.). Psychologia polityczna. (R. Andruszko, Trans.). Kraków: Wydawnictwo Uniwersytetu Jagiellońskiego.

Mazur-Bubak, M. (2020). Domination through the management of fear: The foreign policy of the Russian Federation towards Eastern European states: Between soft and bard power (article under review).

Mierzyńska, A. (2018). Rosyjska propagande szerza polskie portale. Retrieved from: https:// oko.press/rosyjska-propagande-szerza-polskie-portale-znalezlismy-23-takie-witryny/ (30.08.2018).

Military balance. (2015). Military balance. The annual assessment of global military capabilities and defense economics. The International Institute for Strategic Studies. Retrieved from: https://www.iiss.org/publications/the-military-balance/the-military-balance-2015 (20.11.2019).

Miller, P. (2019). Deutche Marine — słabe ogniwo NATO. Raport: Wojsko - Technika Obronność, 1, 28-33.

Morgenthau, H.J. (1948). Politics among nations. The struggle for power and peace. New York: A.A. Knopf.

NATO (2019). NATO cyber defence. Retrieved from: https:/www.nato.int/nato_static_fl2014/ assets/pdf/pdf_2019_02/20190208_1902-factsheet-cyber-defence-en.pdf (10.01.2020).

Newman, B. (1999). The mass market of politics. Democracy in an age of manufacture image. Thousand Oaks: Sage Publications.

Nussbaum, M. (2012). The new religious intolerance overcoming the politics of fear in an anxious age. Cambridge-London: The Celknap Press of Harvard University Press.

Nussbaum, M. (2013). Political emotions: Why love matters for justice. Harvard: Harvard University Press.

Nussbaum, M. (2018). The monarchy of fear: A philosopher looks at our political crisis. New York: Simon and Schuster.

Nye, J. (2009). Konflikty międzynarodowe: Wprowadzenie do teorii i bistorii. (M. Madej, Trans.). Warszawa: Wydawnictwa Akademickie i Profesjonalne.

Pacewicz, P. (2019). Mężczyźni najbardziej boją się gejów i gender, kobiety zapaści ocbrony zdrowia. Wspólny strach o klimat. Retrieved from: https://oko.press/mezczyzni-najbardziej-boja-sie-gejow-i-gender-kobiety-zapasci-sluzby-zdrowia-wspolny-strach-o-klimat/ (07.09.2019).

Pacholska, A. (2007). Wybrane prawne aspekty kradzieży tożsamości w cyberprzestrzeni. Studia Potomac Institute for Policy Studies, 38, 34-52.

Pynnöniemi, K. \& Saari, S. (2017). Hybrid influence - lessons from Finland. NATO Review, 28. Retrieved from: https://www.nato.int/docu/review/articles/2017/06/28/hybrid-influence-lessons-from-finland/index.html (24.11.2019). 
Putin W. (2012). Russia and the changing world. Russia Today, 27.02. Retrieved from: https:// www.rt.com/russia/official-word/putin-russia-changing-world-263/ (26.11.2019).

Reckless campaign (2018). Reckless campaign of cyber attacks by Russian military intelligence service exposed. Retrieved from: https:/www.ncsc.gov.uk/news/reckless-campaign-cyber-attacksrussian-military-intelligence-service-exposed (18.11.2019).

Reykowski, J. (2002). Konflikty polityczne (s. 172-173). In: K. Skarżyńska (Ed.). Podstawy psychologii politycznej. Poznań: Zysk i S-ka.

Robins, R., Post, J. (1987). The Paranoid Political Actor Biography, University of Hawai'i Press, 10(1): 1-19. Retrieved from: https://muse.jhu.edu/article/372124/summary\#info_wrap (12.11.2019).

Sendek, R. (2019). Oślepiający puchacz. Polska Zbrojna, 4, 66-69.

Skarzyński, R. (1992). Od chaosu do ładu politycznego. Carl Schmitt i problem tego, co polityczne. Warszawa: Von Borowiecky.

Swanson, D. (1970). The Paranoid. Boston: Little Brown and Company.

Thornton, R. (2015). The changing nature of modern warfare responding to Russian Information Warfare. The RUSI Journal, 4, 40-48.

Tokarczuk, O. (2019). Facts - 2018. Retrieved from: https://www.nobelprize.org/prizes/ literature/2018/tokarczuk/facts/ (09.12.2019).

Tukidydes. (1988). Wojna peloponeska. (K. Kumaniecki, Trans.). Warszawa: Czytelnik.

Wanless, A. \& Berk, M. (2017). Participatory propaganda: The engagement of audiences in the spread of persuasive communications. Conference: Social Media \& Social Order, Culture Conflict 2.0, Oslo. Retrieved from: https://social-media-and-social-order.neocities.org/ (12.03.2020).

Weber, M. (2002). Gospodarka i społeczeństwo. (D. Lachowska, Trans.). Warszawa: Wydawnictwo Naukowe PWN.

Wilson, A. (2015). Four types of Russian propaganda. Aspen Review, 4, 77-81.

Zielonka, J. (2018). Kontrrewolucja - liberalna Europa w odwrocie. (J. Bednarek, Trans.). Warszawa: Wydawnictwo Naukowe PWN. 